\title{
Assessment of a Pipeline Route in a Karst Terrain, Florida, USA
}

Can Denizman* and Eric Parrish

Department of Physics, Astronomy and Geosciences, Valdosta State University, Patterson Street, Valdosta, GA 31698, USA

*Corresponding author: Can Denizman, Department of Physics, Astronomy and Geosciences, Valdosta State University, Patterson Street, Valdosta, GA 31698, USA, Tel: 229-412-7620; E-mail: cdenizma@valdosta.edu

Rec date: August 30, 2017; Acc date: September 20, 2017; Pub date: September 22, 2017

Copyright: (c) 2017 Denizman C, et al. This is an open-access article distributed under the terms of the Creative Commons Attribution License, which permits unrestricted use, distribution, and reproduction in any medium, provided the original author and source are credited.

\begin{abstract}
A pipeline, known as Sabal Trail Pipeline, for natural gas transport has been proposed to extend from Alabama to Florida, passing through a very fragile and mostly uncovered karst terrain in Florida. There is considerable concern as to the structural integrity of the pipeline as well as its potential impacts on the environment, particularly on groundwater quality of the Floridan aquifer. Using Geographic Information Systems, this study examines the extent of karst in the proposed trail route and suggest two new alternative routes with significantly less karst development. Mean depression density within $5 \mathrm{~km}$ of the proposed Sabal Trail route is 5.2 depressions per $\mathrm{km}^{2}$, with a spatial coverage of $12.2 \%$. Depressions within the alternative route have significantly lower density -2.1 depressions per $\mathrm{km}^{2}$ and much smaller spatial coverage; $5.7 \%$. The routes were also compared with respect to intersected land cover categories.
\end{abstract}

Keywords: Groundwater; Contamination; Geology; Hydrology

\section{Introduction}

Karst aquifers, with their direct connection to the surface via solutional features, such as dolines and swallets, are known to be particularly susceptible to contamination that originates from surficial processes. Rapid groundwater flow within enlarged cavities and conduits with little or no natural remediation results in complicated contaminant plumes that could not be accurately modeled with conventional modeling techniques developed for Darcian flow in homogeneous and isotropic media (for a thorough review of groundwater models in karst aquifers [1]). In addition to groundwater contamination, dissolution-induced ground instability in karst areas often poses significant threats to structural integrity of engineering projects. Therefore, special care should be taken in their design and siting (see Milanovic [2] for a thorough review of engineering practices in karst).

Recently, a pipeline called Sabal Trail Pipeline (STP) is proposed for construction in Florida's karst areas. It will eventually extend 516 miles $(\sim 836 \mathrm{~km})$ from Alabama to Orlando to carry natural gas. Its path takes it underneath three major rivers -the Suwannee and Santa Fe in Florida, and the Withlacoochee in Georgia. It passes through pristine ecosystems, springs, and caves of Florida following a path where the Floridan aquifer is unconfined or semiconfined (Figure 1). Considering the vulnerability of karst aquifers to environmental stresses, there is a great deal of justifiable concern about the proposed route for the STP. Unlike petroleum, natural gas leaking from the pipeline is not expected to be a threat to the Floridan aquifer groundwater quality. It could dissipate to a solutional cavity where it could become trapped and eventually cause an explosion hazard. Groundwater quality is more likely to be adversely affected during the construction of the pipeline, especially during drilling into the karstic bedrock. More serious risks have to do with securing and maintaining the structural integrity of the pipeline in a sinkhole prone terrain.
This study aims to determine the extent of karst and distribution of land cover categories around the proposed STP. An alternative route based on geologic and hydrologic factors is also attempted in this study.

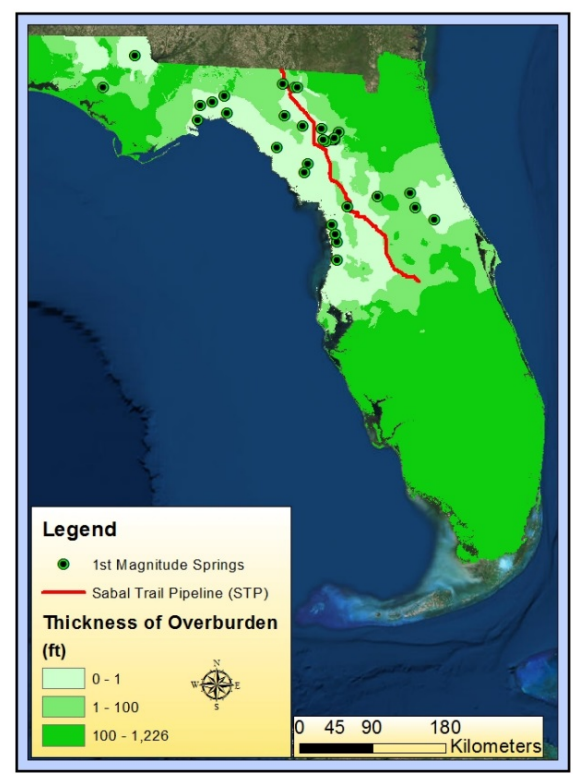

Figure 1: Confinement of the Floridan Aquifer [3]. 


\section{Hydrogeologic Setting}

Highly karstified Tertiary carbonates of the Florida platform host one of the most prolific karst aquifers in the world, the Floridan aquifer. Covered by the varying thickness of siliciclastic deposits and some interlayering carbonates, the Floridan aquifer is confined or semiconfined in most of the peninsular Florida. Only around the Suwannee River area the overlying impermeable units are mostly eroded, bringing about unconfined conditions for the aquifer $[4,5]$.

Floridan aquifer is the most important groundwater resource in most of Florida, and southern Georgia. About $90 \%$ of the Florida population use groundwater from the Floridan aquifer. More than $1 / 3$ of the largest springs in North America discharge from the Floridan aquifer with an average discharge rate nearly 8 billion gpd [6]. The distribution of 1st magnitude springs -those discharging more than $100 \mathrm{ft}^{3} / \mathrm{sec}$ - seems to be controlled by the thickness of the confining unit (Figure 1). They occur where the karst has progressed more efficiently in unconfined or semiconfined areas [7].

Due to over pumping in order to meet the demands of growing population, and increased unfavorable land use practices, the Floridan aquifer has been under significant environmental stress. Saltwater intrusion in coastal areas, drawdown-induced sinkhole formation in overpopulated areas, and cultural eutrophication of once-pristine Florida springs are all too common. Groundwater quality, especially within the unconfined or semiconfined parts of the Floridan aquifer, is under significant risk of degradation.

\section{Data and Methods}

In an attempt to explore the sinkhole-induced risks to the proposed pipeline and assess potential for harm to the Floridan aquifer by the construction of STP, spatial analyses of Geographic Information Systems (GIS) data layers were carried out in this study. Most of the spatial data had already been made public by the Florida Geologic Survey (FGS) (http://www.dep.state.fl.us/geology/programs/ hydrogeology/fava_gis_data.htm) or USGS (https://nationalmap.gov/ landcover.html). Only the proposed pipeline (STP) route was created in this study by digitizing over aerial photography.

Land cover and topographic depression distributions in and around the proposed STP were determined using the following layers:

The National Land Cover (NLCD 2011 Edition, amended 2014) layer is made available by USGS. Its resolution is $30 \mathrm{~m}$.

Topographic Depressions layer includes polygons that shows closed and hachured contours in 7.5-minute topographic quadrangles, and points of centroids for depressions. They were prepared by the Florida Department of Environmental Protection (FDEP).

The percentages of various land cover categories and the topographic depressions intersected by and contained within $5 \mathrm{~km}$ of the proposed STP route were determined using geospatial analysis functions of ArcGIS.

Data obtained from FGS had been prepared for the Floridan Aquifer Vulnerability Assessment (FAVA) [3], and include the following GIS layers:

Soil Permeability represents infiltration through vadose zone. Higher values of soil permeability are interpreted as increasing vulnerability of the Floridan aquifer to surficial contamination (Figure 2).

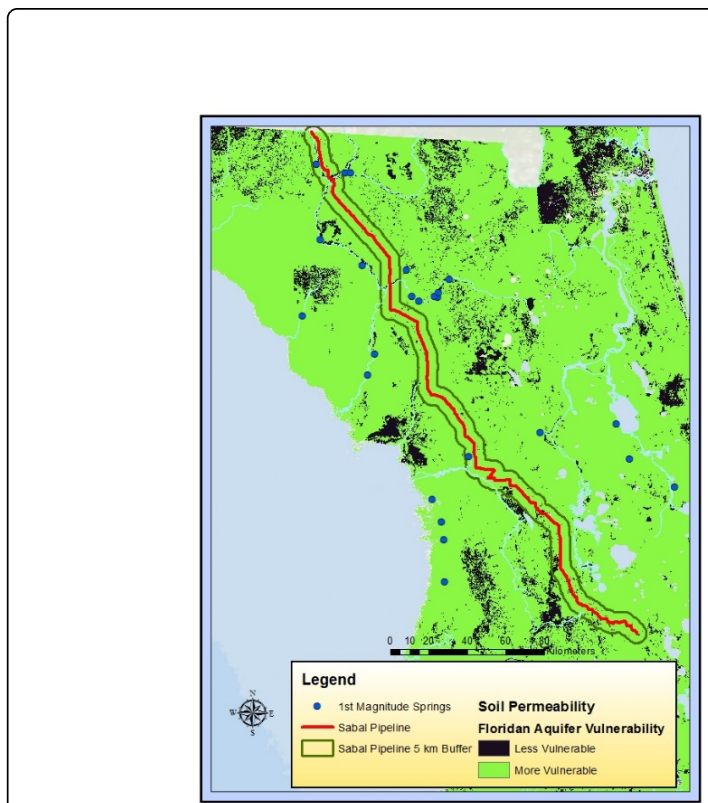

Figure 2: Soil permeability and Floridan Aquifer vulnerability [3].

IAS (Intermediate Aquifer) Thickness represents the thickness of overburden above the Floridan aquifer. The thicker the layer, the less vulnerable the aquifer is to surficial contamination (Figure 3 ).

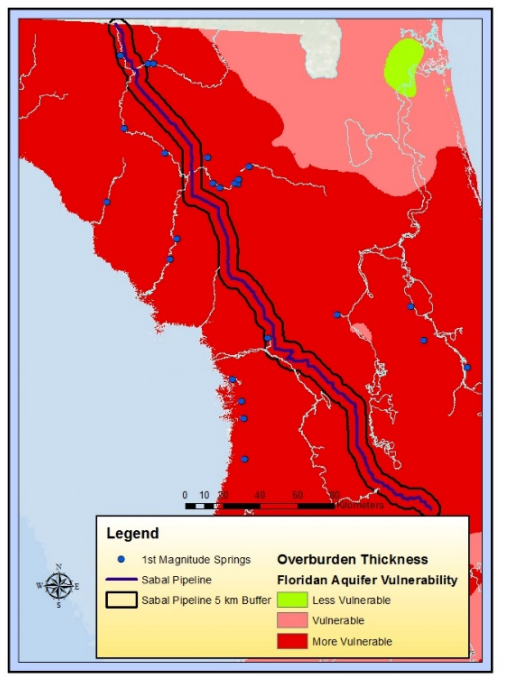

Figure 3: Overburden thickness and Floridan Aquifer vulnerability [3].

Hydraulic Head Difference represents the head difference between the surficial aquifer and the underlying Floridan aquifer. High values indicate downward flow to the Floridan aquifer, rendering the groundwater more vulnerable to contamination (Figure 4). 


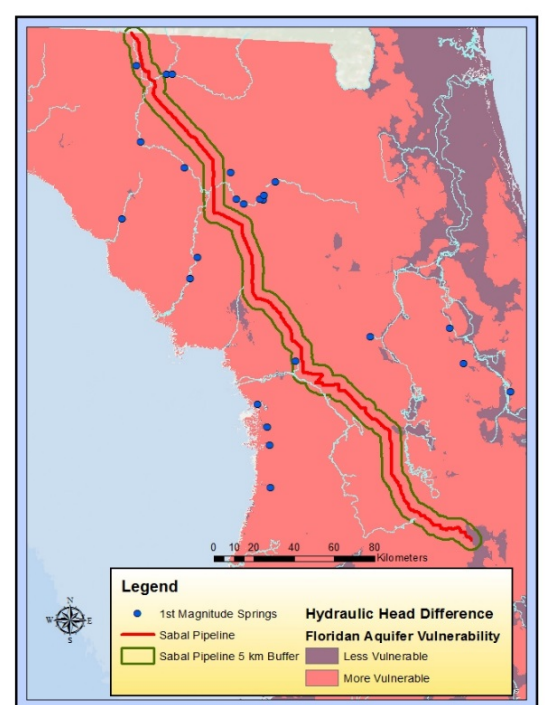

Figure 4: Hydraulic head difference and Floridan Aquifer vulnerability [3].

Finally, in this study, centroid points of polygons that represents depressions from 7.5-minute topographic maps were used to calculate:

Topographic Depression Density based on the depression area. The higher values indicate more vulnerability to surficial contamination (Figure 5).

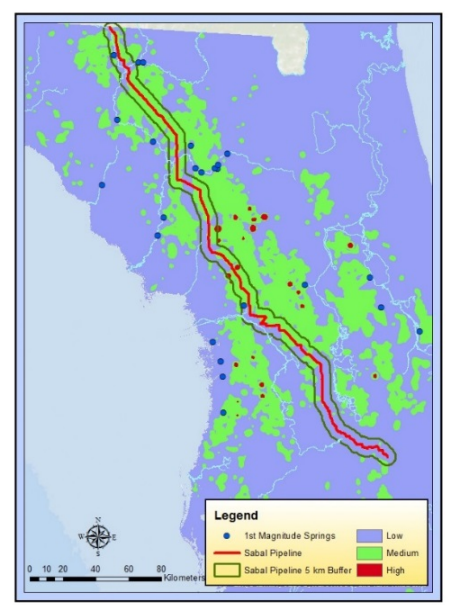

Figure 5: Topographic depression area density and Floridan Aquifer vulnerability.

Using these four layers as cost (or "event") layers, an alternate route ("cost path") for the pipeline was determined by means of Cost functions in ArcGIS. Preparation of "event" layers is explained in detail by Arthur et al. [3] for the Floridan Aquifer Vulnerability Assessment (FAVA) model. In this study, no changes were made to the internal weights calculated for the FAVA model, which include values from 1 to as high as 3 assigned to each cell. Topographic Depression Density layer was divided into 3 classes by the natural breaks (Jenks) function and assigned values from 1 to 3 with increasing risk for harm to groundwater quality.

Once the "Cost Grid" is calculated by adding the four event layers (Figure 6), the Cost Path tool was used to determine the least-cost path from a destination point to a source [8]. This path is one cell wide and guaranteed to be the cheapest route, i.e., least harmful to the Floridan aquifer, relative to the cost units defined by the four layers described above.

The calculated least cost path, called Alternate Route 1 (AR-1), however, goes through a number of heavily populated urban areas. Therefore, it was edited to generate Alternate Route 2 (AR-2) (Figure $6)$.

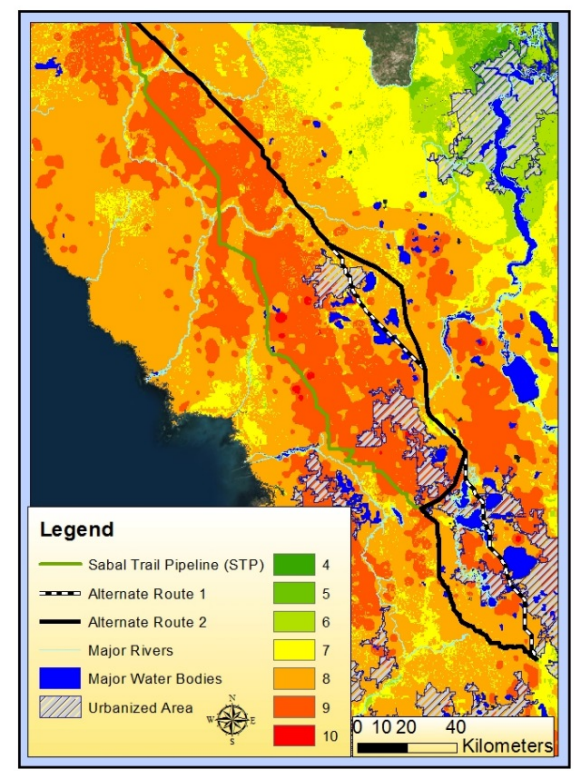

Figure 6: Cost Grid: degree of harm to Floridan Aquifer (4 to 10); Least Cost Path: least harm pipeline paths (Alternate Route-1 and Alternate Route 2).

\section{Results and Discussion}

Intensive karst development along the proposed route of STP, readily observed in Figure 7, suggest that spatial distribution of karstic features was not considered to be critical in the decision process. The reasoning behind this particular pipeline route is hard to understand, as karst areas pose significant risks to engineering projects, especially to a pipeline that extends hundreds of kilometers over well-developed depression and cave systems. 


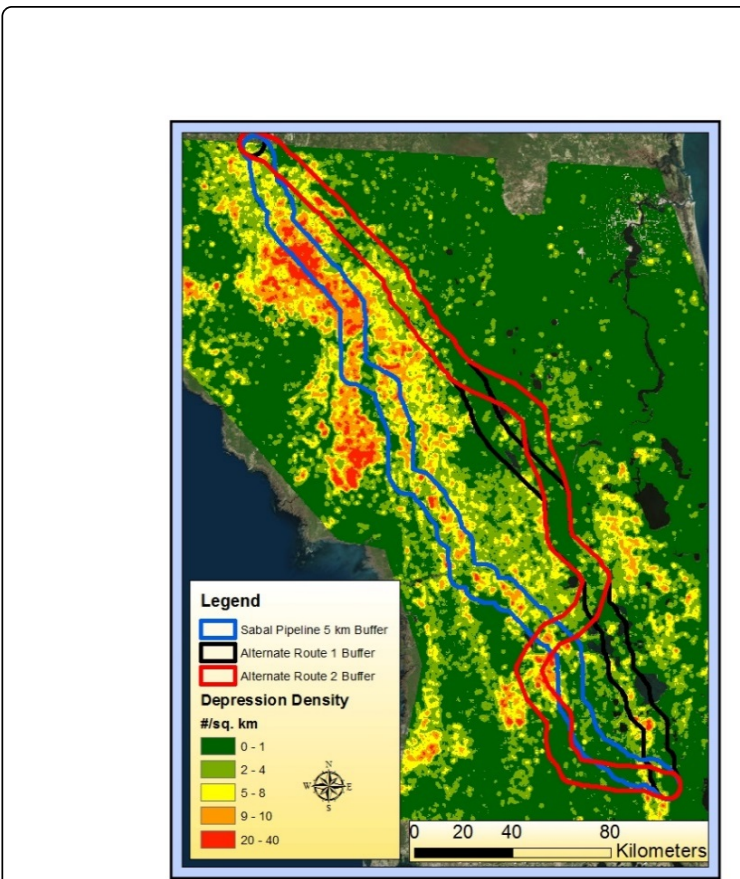

Figure 7: Karstic depression density.
Table 1 shows the extent of karst development around the STP route as well as the two alternate routes proposed in this study. About $13.7 \%$ of the $376.4 \mathrm{~km}$-long STP pipeline occurs in karstic depressions, whereas only $4.2 \%$ of the $331.8 \mathrm{~km}$-long AR- 1 is intersected by them. Karstic depressions on AR-2 is $4.8 \%$ of the $375.1 \mathrm{~km}$ long route. Within a $5 \mathrm{~km}$ buffer of each route, the percentages of karstic depression areas are 12.2 and 6.7 for the STP and the AR-1, respectively. Some $5.7 \%$ of the total $5 \mathrm{~km}$ buffer area around AR-2 is comprised of depressions.

Moreover, there is significant contamination risk for the Floridan aquifer in and around the STP route. The pipeline, constructed directly on top of the Cathedral-Falmouth cave system, encompasses a total of 44 springs within its $5-\mathrm{km}$ buffer, including three 1 st magnitude springs (Table 1). Groundwater contamination, although not anticipated during the operation of the pipeline, is definitely an issue at the construction stage. There has been at least one case of drilling mud leak to the aquifer even at this preliminary stage of the construction. More accidental spills seem to be likely.

Depression densities within $5 \mathrm{~km}$ of each route show a similar pattern (Table 2). The proposed STP buffer zone has more than twice as much mean depression density (5.2 depressions $\left./ \mathrm{km}^{2}\right)$ as AR-2 (2.1 depressions $/ \mathrm{km}^{2}$ ). In other words, the proposed path for the STP has significantly more karstic depressions with larger total depression area and density.

\begin{tabular}{|l|l|l|l|l|}
\hline & $\begin{array}{l}\text { Length Intersected by } \\
\text { Depressions (\%) }\end{array}$ & $\begin{array}{l}\text { Depression Area Within 5 km } \\
\mathbf{( \% )}\end{array}$ & $\begin{array}{l}\text { Number of Springs Within 5 } \\
\mathbf{k m}\end{array}$ & $\begin{array}{l}\text { Number of 1st Order Springs } \\
\text { Within 5 km }\end{array}$ \\
\hline Sabal Trail & 13.7 & 12.2 & 44 & 3 \\
\hline Alternate Route 1 & 4.2 & 6.7 & 19 & 2 \\
\hline Alternate Route 2 & 4.8 & 5.7 & 19 & 2 \\
\hline
\end{tabular}

Table 1: Karstic Depressions and springs around pipeline routes.

\begin{tabular}{|l|l|l|l|}
\hline & $\begin{array}{l}\text { Number of Depressions } \\
\text { Within } \mathbf{5} \mathbf{~ k m}\end{array}$ & $\begin{array}{l}\text { Mean Depression Density } \\
\text { Within } \mathbf{5} \mathbf{~ k m}\left(\mathbf{p e r} \mathbf{~ k m}^{2}\right)\end{array}$ & $\begin{array}{l}\text { Maximum Depression Density Within } \mathbf{5} \\
\mathbf{k m}\left(\mathbf{p e r ~} \mathbf{k m} \mathbf{~}^{2}\right)\end{array}$ \\
\hline Sabal Trail & 18,645 & 5.2 & 26.7 \\
\hline Alternate Route 1 & 6772 & 2.8 & 32.8 \\
\hline Alternate Route 2 & 8025 & 2.1 & 32.8 \\
\hline
\end{tabular}

Table 2: Depression densities around pipeline routes.

These numbers suggest that the proposed STP route, extending through the heavily karstified area of the Florida peninsula is not the safest path with respect to the structural stability and environmental conditions of the Floridan aquifer. In fact, new sinkhole formations have already been reported in and around the construction site of the pipeline.

\begin{tabular}{|l|l|l|l|}
\hline Developed, Open Space & 7.3 & 6.9 & 6.0 \\
\hline Developed, Low Intensity & 2.3 & 2.5 & 2.1 \\
\hline Developed, Medium Intensity & 0.1 & 0.7 & 1.1 \\
\hline Developed, High Intensity & 0.2 & 0.2 & 0.2 \\
\hline
\end{tabular}

\section{\begin{tabular}{l|l|l} 
STP & Alternate 1 & Alternate 2
\end{tabular}}


Citation: Denizman C, Parrish E (2017) Assessment of a Pipeline Route in a Karst Terrain, Florida, USA. J Remote Sensing \& GIS 6: 210. doi:

$$
\text { Total }
$$

$$
9.9
$$$$
10.3
$$$$
9.4
$$

Table 3: Development around pipeline routes.

Distributions of land cover categories around the proposed STP and the alternate routes are given in Figures 8 and 9. There are some apparent differences in land cover distributions between the proposed STP and the alternate routes delineated in this study. In particular, less wetland area is intersected by or contained within $5 \mathrm{~km}$ of the proposed STP route. It is beyond the scope of this study to assess the proposed STP in light of the environmental regulations. Nevertheless, natural gas pipelines are considered to pose much more significant hazard risks in developed, urbanized areas. A breakdown of "developed" land cover category for the three routes is given in Table 3. AR-2 seems to have slightly less spatial coverage of each subcategory of development except for the "Medium Intensity."

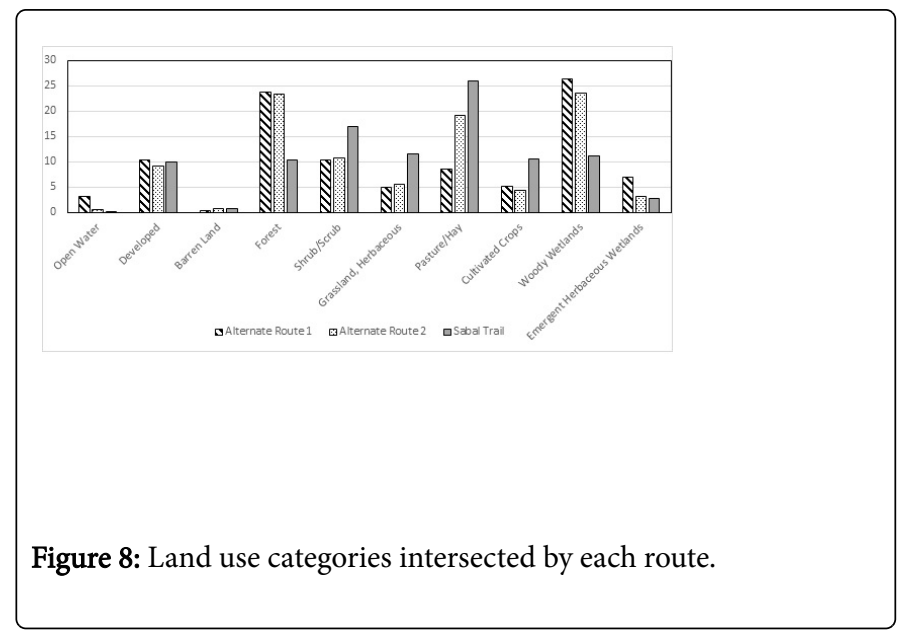

In conclusion, an impartial assessment of proposed STP and alternative routes attempted in this study clearly shows that there is significant karst-related structural and environmental risk with the STP route. Considering the distribution of karstic depressions and land cover categories, AR-2 stands out as the best option for the proposed pipeline.

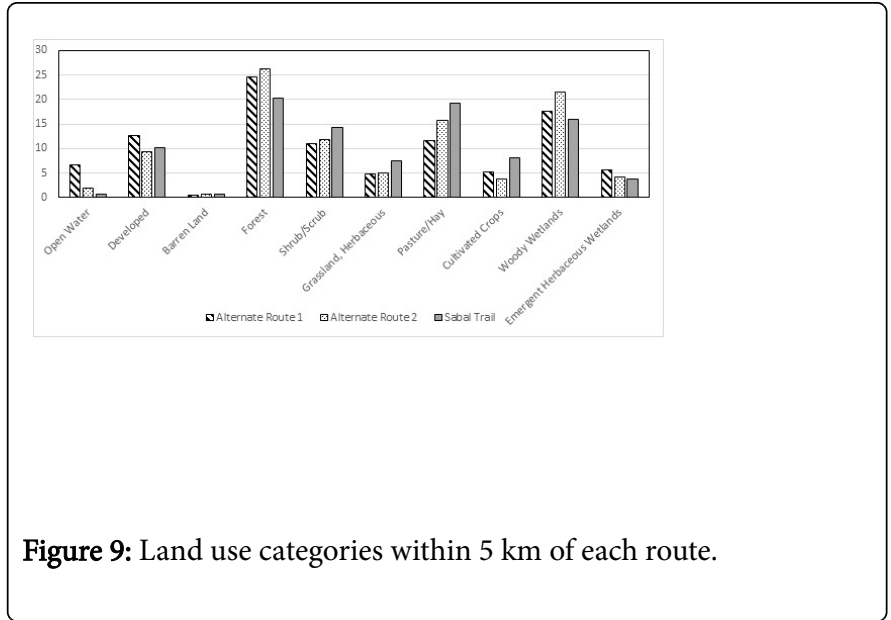

\section{References}

1. Hartmann A, Goldscheider N, Wagener T, Lange J, Weiler M (2014) Karst water resources in a changing world: Review of hyrological modelling approache. Rev Geophys 52: 218-242.

2. Milanovic PT (2000) Geological engineering in karst. Zebra, Windhoek, Namibia.

3. Arthur JD, Baker AE, Clichon JR, Wood AR, Rudin A (2005) Florida Aquifer Vulnerability Assessment (FAVA): Contamination potential of Florida's principal aquifer systems, A report submitted to the Division of Water Resource Management, Florida Department of Environmental Protection. Florida Geological Survey.

4. Stringfield VT, LeGrand HE (1966) Hydrology of Limestone Terranes in the Coastal Plain of the Southeastern United States. Geological Society of America Special Papers 93: 1-46.

5. Miller JA (1986) Hydrogeologic framework of the Floridan aquifer system in Florida and in parts of Georgia, South Carolina, and Alabama. US Geological Survey Professional Paper.

6. USGS (1995) US Geological Survey Fact Sheet.

7. Miller JA (1997) Hydrogeology of Florida. In: The Geology of Florida. University Press of Florida, USA, pp: 57-68.

8. McCoy J, Johnston K (2001) Using ArcGIS spatial analyst: GIS by ESRI. Environmental Systems Research Institute. 